EXEMPLARIa Classica

Journal of Classical Philology

23, 2019, $\mathrm{xx}-\mathrm{xx}$

ISSN 1699-3225

\title{
HORACE'S BOOK 2 OF ODES. SOME REMARKS ON THE NEW “GREEN AND YELLOW” COMMENTARY*
}

\author{
NiCOLETTA BRUNO \\ LMU München \\ nicoletta.bruno88@yahoo.it
}

1. Eduard Fraenkel's legacy in the works of Robin Nisbet, especially in the three commentaries of the Carmina of Horace, written with Margaret Hubbard and then Niall Rudd, can be observed in the new work by Stephen Harrison, despite the necessary progress and change of theoretical and literary approaches. Commentaries, just like critical editions, need updates, even when the work that is being replaced is one of the canonical and magisterial commentaries in classical studies, as is that of Robin Nisbet and Margaret Hubbard's second book of the Odes of Horace (Oxford, 1978). This task of substitution, or rather integration, of the work of Nisbet-Hubbard, comes at this time appropriately from the Oxonian school, and from one of the most productive and erudite scholars of Horace and a pupil of Robin Nisbet.

Great commentaries on the Odes of Horace in the last century were not lacking. More than fifty years after its last edition, the Kiessling-Heinze commentary $\left(1884,1^{\text {st }}\right.$ edition $-1930,7^{\text {th }}$ edition $)$ on the three first books of the Odes still remains a major interest for scholars. The work was much revised by Richard Heinze, and this commentary «raises some interesting issues about a scholar taking on and revising an existing commentary by another hand. (...) There seems little doubt that the Kiessling-Heinze commentary became more sophisticated over time, due at least partly to Heinze's great talent as a literary critic as well as to his growing academic status». ${ }^{1}$ The first NisbetHubbard commentary on Odes I appeared in 1970 and was immensely more detailed than the three commentaries by E. C. Wickham in the nineteenthcentury Oxford series. It could undoubtedly to be said that it superseded Heinze's work, not just for English scholars, but for scholars everywhere. The commentaries on the three oxonian books of Horatian Carmina (Nisbet-

1* Stephen Harrison (ed.), Horace: Odes, Book II. Cambridge Greek and Latin Classics. Cambridge: Cambridge University Press, 2017, pp. ix+267, ISBN 978-1-107-60090-4.

S. Harrison, Two-author Commentaries on Horace. Three-Case Studies, in Classical Commentaries: Explorations in a Scholarly Genre edited by C.S. Kraus and C. Stray, Oxford 2015,75 . 
Hubbard 1970, Nisbet-Hubbard 1978 and Nisbet-Rudd 2004)² indeed take much from Fraenkel's work, especially its historicist concerns, its focus on literary patterning and models, and on literary history. However, they also differ from it in some key themes and aspects: his interest in the literary evaluation and in the later reception of Horatian poems, a more nuanced approach to the poet's use of the first person, and a less idealistic approach to the poetry's political context. Nisbet and Hubbard have always denied doing literary criticism, influenced by Housman's celebrated but strict view that scholarship and literary criticism are separate gifts, rarely combined in the same person. ${ }^{3}$

«Each generation will need new commentaries and we must work to foster new kinds of commentary to meet those needs», ${ }^{4}$ that is Elaine Fantham's sharp reflection on the need to renew the commentaries. Nisbet completely changes the line of his thought and showed a more complete maturity and a greater distance from the way he commented Horace in the '70s. In 2004 appeared his commentary on Book 3 of Horace's Odes in collaboration with Niall Rudd. As Harrison himself recalled, Niall Rudd a few years earlier had contacted the former director of the "Cambridge series Greek and Latin Classics”, E.J. Kenney, asking to write the commentary on Book 4 of Horace's Odes, already commissioned to Richard Thomas. Rudd recalled that Nisbet was working on a larger scale project on that same book (Book 3 ) and contacted him to see if he was interested in a collaboration to finish the commentary project on the Horatian Odes. Nisbet-Rudd's commentary is the closest point of reference for the new commentary by Stephen Harrison. As Paolo Fedeli writes: «ho la netta sensazione che l'evoluzione dei commenti oraziani, da Nisbet-Hubbard a Nisbet-Rudd, attesti una progressiva presa di coscienza dei limiti del commentare per lemmi: nei due di Nisbet-Hubbard, infatti, vige un rigido rispetto della lemmatizzazione; di conseguenza il lettore, al quale non viene offerto il testo dei singoli carmi, procede attraverso i vocaboli e le iuncturae selezionati dai commentatori, e se non ha fra le mani un'edizione oraziana ignora quale sia, nel suo coerente

2 The original commentary team was to have consisted of four Oxford colleagues (Nisbet, Hubbard, A. F. Wells and Gordon Williams). The team rapidly reduced to two: Wells suffered from severe illness and died in 1966. Williams moved to the Chair of Humanity at St. Andrews in 1963 and was no more involved in the Oxford project. All the four-person team were connected with Eduard Fraenkel, whose major work Horace, itself replete with many close analyses of the Odes had come out in 1957. The experience at ThlL for Margaret Hubbard was no doubt Fraenkel's suggestion, as he himself had worked on it during the First World War, and as proofreader for the Vol. VII. 1 in the 1960s. Cf. S. Harrison, Two-author ... 2015, 76.

${ }^{3}$ A.E. Housman, The Name and Nature of Poetry, Cambridge 1939, 1.

4 E. Fantham, Commenting on Commentaries: A Pragmatic Postscript, in The Classical Commentary. Histories, Practices, Theory, ed. by R.K. Gibson and C. S. Kraus, Leiden-Boston-Köln 2002, 419. 
sviluppo, il dettato poetico dell'autore»..$^{5}$ I quote again Elaine Fantham, who in her commentary on Senaca's Troades chose to depart from the old habit of commenting on lemmata, and clarified the reasons and the purposes of the preference for "a running interpretation», when she stated: «my hope was to avoid the indigestible fragmentation of the usual commentary format, and de-emphasize the lemmata as mere signposts linking commentary to text rather than privileging them with a higher level of significance than words not lemmatized». ${ }^{6}$

It is worth focusing on this important point concerning the debate on how to write commentaries and on the possible limits of some editorial choices that continue to affect the commentators. Harrison's work, fitting within the tradition of the Cambridge commentaries, is synthetic and selective, but manages to perform the miracle, as happens in other praiseworthy and recent examples, of being exhaustive. I am sure that the requirement of synthesis only contributed to the already enormous effort of the commentator, already engaged in interpreting the text, to make it his own and to recreate it. Writing a commentary requires knowledge, imagination, and a good judgment. Harrison's commentary is partly lemmatized, but also divided by sections of verses, just like Nisbet-Rudd, or "pseudolemmata" because they include whole verses or groups of verses, without omitting even one, and in their context the discussion is continuous.

2. In accordance with the general format of the Cambridge "Green and Yellow" series, the book is structured as follows: preface, references and abbreviations, introduction, text, commentary, bibliography and indices. The Introduction in about twenty pages draws together many different aspects concerning the literary career of Horace, the problems of dating Book 2 of the Odes, the structure of the book and of the individual poems, intertextuality, the poems' "internal architecture" (with a focus on ring composition, central pivots, and closural devices), style (with a stylistic reading of Odes 2,14), meters and text. Book 2, with its twenty poems, is the most clearly organized in the collection and shows a metrical uniformity: all but two poems (carm. 2, 12 in the Asclepiadean meter and 2, 18 in Hipponactean meter) are either in Sapphic or Alcaic meters. For what concerns the length of the individual poem there is a general uniformity, as well as in the themes. One of the first

${ }^{5}$ P. Fedeli, "I dubbi e i ripensamenti di un commentatore", Paideia» 66, 2011, 691. On Nisbet-Rudd commentary cf. P. Fedeli, "L'Orazio di Nisbet-Rudd. Riflessioni sull'arte di commentare", ExClass 13, 2009, 11-26.

${ }^{6}$ «Per parte mia continuo a credere che in un commento il procedere per sezioni di senso anziché per lemmi costituisca un vantaggio, perché è il modo più efficace per far sentire la voce del commentatore e per mettere il lettore in condizione di cogliere, grazie ad essa, il significato di un contesto: gli svantaggi si riducono sostanzialmente a uno solo, cioè al maggior tempo necessario per rintracciare, all'interno di un discorso continuo, un particolare che interessa». Cf. P. Fedeli, "I dubbi...", 2011, 710-1. 
problem to solve is the publication of Book 2 of the Odes. If Odes 1, 1 and the 3,30 have the character of prologue and epilogue respectively, there are no clear clues in Book 2.

The collection emerged as a unit about $23 \mathrm{BCE}$, but it has been suggested more recently, by Gregory Hutchinson in particular, ${ }^{7}$ that its individual books might also have been published separately in chronological order. This suggestion fits Odes 2, the central book of the collection, where the poet seems to react in particular to Virgil's Georgics, published in 29 BCE. The few topical indications in the book suit the period 28-25. ${ }^{8}$ Harrison's discussion of Horace's literary career draws interesting connections between his changing poetic genres and his poeticized autobiography, each of which is "marked by a rhetoric of literary and socio-political ascent", to quote Harrison. It is possible that it was also published serially in single books: the collection of Odes 1-3, which emerged as a unit about 23 BCE, should be conceived as a single stage in Horace's poetic career. Odes 2 belongs in the middle phase of Horace's "long and carefully-modulated poetic career." The notion of the "middle way" in fact guides Harrison's Introduction. His discussion of Book 2's poetic arrangement, for example, avoids overly elaborate schematizations of the poems while pointing out their most important themes, images, ideas, and structures.

The poems of Book 2, according to Harrison, cannot be included in a single thematic scheme, but there are groups of poems with common themes: odes 2, 1-3 are linked by the civil wars and the writing of history, all addressed to real historical figures; $2,4-5$ are paired as two lighter poems of the life of love, involving figures with real names and look back to the poet's past; 2, 8-9 are another pair of poems on erotic subjects, while the three poems 2, 10-12 are linked by the prominence of death and the underworld. Odes 2, 13-14 are paired by the prominence of death and the underworld in both poems, while 2,14 and 2,15 stand together as poems of ethical advice against luxury. The final group of four odes is contained by two poems addressed to Maecenas, both of which stress the poet's friendship, but 2, 19 and 2,20 are also paired together because of their imaginative fantasy about immortals, 2, 19 with the description of the divine Bacchus, and 2, 20 with the description of immortalized poet. These similarities are accompanied and balanced by contrasts and alternations, which like the variety of addresses. The addressees of Horace's Odes have attained more critical attention since the work of Nisbet and Hubbard, in particular in the important analysis of

G. Hutchinson, Talking Books: Readings in Hellenistic and Roman Books of Poetry, Oxford 2008, 131-61.

${ }^{8}$ The reference to the restoration of Phraates IV to the throne of Parthia in 2, 2 points to 25, while the allusions to the wars against the Cantabrians in Spain in 2, 6 and 2, 11 fit 29-26. 
Mario Citroni, ${ }^{9}$ but no one has considered the addressees of initial poems in their chronological order and against the background of Horace's developing poetic career. The initial addressee of a verse-collection in Latin poetry of Augustan date is usually deemed to be the dedicatee of the whole book, following the precedent of Catullus, where the first poem of the extant collection plainly dedicates a poetic book to Cornelius Nepos (whatever the nature and identity of the book it in fact introduced), and of the first and second books of Propertius, in which the initial poems address the prestigious Tullus and Maecenas respectively $(1.1 .9,2.1 .17)$, who are likely to be the dedicatees of the respective books.

The recurrent ethical focus is on moderation and austerity, while the addressees tend to be men of middle rank. The second book of the Odes is a "book of moderation". The moderation is across a range of fields - in material consumption, in philosophical outlook, in passions and emotions, and in literary form. Suffice to mention the opening poem: after a recall of the horrors of civil war treated by its addressee Pollio in his lost Histories, "the last stanza famously implies that this material is excessive for Horatian lyric $(2,1,37-40)$, both in implicit contrast with the dramatic history of Pollio evoked in the rest of the poem and in the explicit contrast with the intense lyric laments associated with the name of Simonides of Ceos", points out Harrison.

For what concerns the selection of addressees in Book 2, there is a wide variety in more than meter and length. A quarter of the poems is addressed to minor friends of Horace, some of whom are also addressed in the first book of the Epistles (Septimius, Pompeius, Quintus, Postumus and Grosphos). The most influential friend, Maecenas, is the addressee in three odes. Pollio, Sallustius, the great-nephew of the famous historian, and the rich Dellius are the addressees of the first three odes, linked with the historic topic and with the civil war. There are only two fictional addressees (Xanthias and Barine), because the number of the love odes is smaller than the in Book 1. The role of philosophy in Book 2 is prominent. ${ }^{10}$ Horace comes across in the main topics of the contemporary schools of philosophy: the correct use of wealth, the importance of equanimity in good and bad times, the proper limits of lamentation, the evils of excessive materialism and the virtue of austerity and the primacy of inner peace. Stoic, Epicurean and Peripatetic elements are perfectly combined in many odes. There is a clear penchant for Epicureanism, due to the emphasis on the notions of enjoying life and seeking $133-214$.

${ }^{9}$ M. Citroni, "Occasioni e piani di destinazione nella lirica di Orazio", $M D$ 10-11, 1983,

${ }^{10}$ The prominence of philosophical elements in Odes Book 2 has often been noted by scholars, especially H.-C. Günther, "The First Collection of Odes: Carmina I-III" in H.-C. Günther (ed.), Brill's Companion to Horace, Leiden-Boston 2013, 316-17. Moderation is also a key topic of Book 1 of Epistles. 
private contentment in escape from public affairs, friendship, symposium and erotic elements, that are also typical of the tradition of Greek lyric poetry. Alessandro Barchiesi pointed out that Horace, as no other poet in antiquity, invites psychological biographism. This is a fundamental trait of Horace's poetry and its deeply personal character, ${ }^{11}$ as regards his family background, his friendships, the external vicissitudes of his life. Horace ostentatiously paints a very distinct image of himself by conscious self-stylization.

In the chapter "Literary intertext", Harrison emphasizes Horace's creative allusive ability, especially in the texture of the Odes. A literary genre is a mixture of thematic material and formal features, for contemporary educated readers, especially in the Roman period. According to Tzvetan Todorov: «readers read in function of the generic system, with which they are familiar thanks to the criticism, schools, the book distribution system, or simply by hearsay; however, they do not need to be conscious of this system». ${ }^{12}$

The features that characterize every single genre may be either formal or substantive: what matters is the fundamental concept of literary genre, as applied in Harrison's book, that is a form identified through a particular generic repertoire of external and internal features. How are we to recognize 'generic enrichment'? This literary effect happens when one genre includes, contrasts with or gains from another. "I define 'generic enrichment'» writes Stephen Harrison "as the way in which generically identifiable texts gain literary depth and texture from detailed confrontation with, and consequent inclusion of elements from texts which appear to belong to other literary genres». ${ }^{13}$ This characteristic of 'generic enrichment' is the basis of much Augustan poetry, not only in Virgil and Horace, but also in Tibullus, Propertius and Ovid, and can also be found in the previous poetry of Catullus and Lucretius. However - it must be said - it is not at all a radical innovation, either in classical scholarship or in the debates of generic theories. It could be argued that two well-known ancient theories derive from the Hellenistic period: the first one is the search for a chief exemplar, that is basically the auctor of a genre, as a part of its definition, the second one, is the admission that a genre may incorporate elements from other genres, and this is one of the central elements of Augustan poetry.

Greek lyric is a constant presence in meters and themes. However, the relationship of these works to archaic Greek poetry is not easily grasped, as rightly Hutchinson pointed out. ${ }^{14}$ Archilochus is recognizable in the 'incipit' of Odes 2, 3 and in 2, 7 for the loss of the shield in battle (also suffered by

${ }^{11}$ A. Barchiesi, "Carmina: Odes and Carmen Saeculare", in S. Harrison (ed.), The Cambridge Companion to Horace, Cambridge 2007, 144-62.

${ }_{12}$ T. Todorov, Genres in Discourse, Cambridge 1990, 19.

${ }^{13}$ S.J. Harrison, Generic Enrichment in Vergil and Horace, Oxford 2007, 1.

${ }^{14}$ G. Hutchinson, "Horace and archaic Greek poetry", in S. J. Harrison (ed.), The Cambridge Companion to Horace, Cambridge 2007, 36-49. 
Anacreon and Alcaeus). Sappho and Alcaeus are the most important models in Odes 1-3 for both form and content. Alcaeus is seen as the poet of sailing, exile and war, Sappho as the voice of unrequited homosexual love; Simonides is echoed in allusions to his lyric laments in 2,1 and 2,13 , while a fragmentary poem of Bacchylides seems to be a starting point for 2,18 .

The influence of Greek epigram on Horace's Odes has long been recognized, though it is perhaps underestimated in modern scholarship, as emphasizes Harrison. The brevity and elegance of the epigram form, as well as its considerable range of topics, provided an attractive resource for Horatian remodeling of the stylistically ampler tradition of Greek archaic lyric on Callimachean aesthetic principles. The sample considerations of links with epigram which follow highlight an important source of generic interaction in Horace's Odes which is a crucial determinant of their literary form. The combined deployment of epigrammatic topics and forms makes this an extraordinary lyric poem with several dramatic false closures and allows some insight into the ways in which generic interaction with epigram aided the Horatian project of the modernizing and transformation of archaic Greek lyric for a post-Hellenistic Roman readership. In Book 2 it is particularly visible in 2, 4 (use of Philodemus' catalogue of erotic charms and reference to his own age), 2, 5, 2, 11 and 2, 20, where there are traces of Posidippus' self-presenting sphragis.

There are allusions not only taken from Greek poetry, but there is also a broad range of allusions from extant Roman poetry: Ennius, Lucretius and Catullus. ${ }^{15}$ Carmen 2, 20 is a clear allusion to Ennius in Horace's metamorphosis into a swan of eternal fame. The ode 2, 14 addressed to Postumus famously closes with the thought that the addressee must leave behind his family and earthy possessions once death comes (cf. Lucretius' diatribe against the fear of death in $D R N 3,894-901$ ). The opening of 2,16 to Grosphos is also Lucretian, where the poet praises otium, as the highest goal of life, like Lucretius in 2, 1-39. ${ }^{16}$ Both genres, lyric and didactic poetry, give sententious precepts, through examples and similes. The influence of De Rerum Natura on Horace's poetry also emerges in the hexametric Satires, where the shared metrical form supports intertextual influence. "In the Odes, on the other hand, the self-characterization of Horace as an inspired poet who rejects materialism and scorns the fear of death draws heavily on the lofty self-fashioning of the speaker of the De Rerum Natura,

${ }^{15}$ For what concerns Catullus especially in 2,6, a moderate but warm expression of friendship, where the opening theme of perilous journey into theaters of war and distant lands recalls the famous carmen 11, Furii et Aurelii comites Catulli...

${ }_{16}$ This image occurs not only in Book 3 of Lucretius, but also in DRN 5, 1220-1240. Harrison suggests that Horace's storm-caught sailor in 2, 16 is a military like in Lucretius 2,1-4. 
while consistently accommodating these ideas to the more moderate poetic persona of Horatian lyric». ${ }^{17}$

The first half of the 20s BCE, when Book 2 was published, was a crucial period in the establishment of the Augustan regime after Actium, the year of Augustus, triumphant return and triple triumph (probably just after the publication of the Vergilian Georgics). It is unsurprising that one point of contiguity between the Georgics and Odes 2 is political. Horace uses encomiastic elements from Vergil's poem, and in general Odes 2 supports and increases the political elements of the Georgics. As we have already seen, Horace's lyric book tones down and normalizes the sublime didactic aim of the De Rerum Natura; it seems more familiar with the moderate didactic tone of the Georgics, converging for example with its treatment of materialism. In addition, the lighter element of lyric is also important in Odes 2: for example the topic of the journey to the Underworld. In ode 2, 9 Valgius' lament recalls the lament of Orpheus for the lost Eurydice (2, 9, 9-12 and georg. 4, 465-6): but the tragic episode is ironized in Horace, because the loss of the puer Mystes is not to be compare with the loss of Eurydice.

In the chapter "Style", Harrison focuses on ode 2, 14 to Postumus, particularly illustrative for the stylistic features of the Book. The overall language of Odes 2 is similar to that of Aeneid. The use of the word order is remarkable in the book, especially the use of anaphora and hyperbaton are frequent and striking. Concerning the internal architecture of the poems, the technique of ring-composition is common.

The last chapter clarifies why it is not a full critical text, although Harrison provides a highly selective apparatus criticus and contributes some new conjectures, making use of a resource unavailable to previous commentators of Book 2: the Oslo database, a free online repository of conjectures on Horace's poetry.

3. In what follows, I will focus on some of the most significant points of Book 2, analyzed by Harrison. The commentary for each poem follows the same pattern. Harrison summarizes the poem in a short introduction, identifies the meter, provides a select bibliography, and gives a line-byline analysis. The introductive sections to each poem provide excellent entry-points into the poems, introducing the readers to the main themes, structures, generic interactions and key literary intertexts. Harrison's selection of parallels and evidence to support his readings and interpretations is precise and synthetic. At the end of the Latin text of each ode is reported the main modern bibliography on which the commentary is based. Textual

17 S.J. Harrison, "Didactic and Lyric in Horace Odes 2: Lucretius and Vergil", in Generic Interfaces in Latin Literature. Encounters, Interactions and Transformations, edited by T.D. Papanghelis, S.J. Harrison, S. Frangoulidis, Berlin-Boston 2013, 368. 
criticism problems are adequately addressed with more attention to the most recent interpretations. There is no translation and the critical apparatus is not complete, as already remarked, but it only reports Harrison's variants or conjectures. The absence of the translation is understandable, not only because of the tradition of the "Green and Yellow" series of Cambridge, but also because the illustration of the linguistic aspects is quite frequent.

Book 2 of Odes deals with rather more philosophical and ethical issues than the first book. Both didactic poems, Lucretius' De rerum natura and the Georgics of Virgil exercised a particular influence on Book 2 of Horace's Odes in the 20s BCE. Odes 2, 3, 2,14 and 2,16 are the most philosophical in Book 2. One of the most common philosophical reasons is that which revolves around the concept of metriotes between two opposite excesses of the good and the bad (what Horace in 2, 10 calls aurea mediocritas), theorized by Aristotle, but which were, even before, the cornerstone of Delphic and true wisdom, a "topos" of the popular philosophy.

For instance, several philosophical doctrines, especially Stoicism and Epicureism (Panaetius and Epicurus), are mixed in the eclectic ode 2, 3 to a friend of Augustus, Dellius, who emerged under Dolabella and then joined Anthony, probably after Philippi. The ode wants to be an exaltation of the right balance as a right behavior of life in every situation, both in sad moments and in those carefree and joyous. The solemn memento aequam memento rebus in arduis / servare mentem "maintain equanimity in hard times" marks the didactic character from the first verse. Triumph and disaster have to be treated with equal indifference: the topic is a traditional piece of wisdom, inherited and found already, as remarked by Nisbet and Hubbard, in Archilochus (fr. $128 \mathrm{~W}$.). The uselessness of the concern is given by the ineluctable necessity of death, a strongly Epicurean leitmotif. The didactic example is provided in the third stanza from the world of nature, with the image of the branches of the pines and poplars that come together to provide a pleasant shade and with water that strives to flow into the curved and tortuous bed of the stream. From the representation of natural reality, there is an immediate existential reflection. Here Harrison sees a parallel with Vergil's Eclogues lexicon, for the presence in lines 9-12 of typical bucolic words: pine and poplar are paired in Ecl. 7, 66 and 9, 41, and umbra is a key term in the landscape of the Eclogues, appearing 17 times. Harrison divides the structure of the ode in three parts: the first pair of stanzas which contain an opening exhortation to Dellius to maintain equanimity (1-8), a second pair of stanzas which list the preparations for a symposium (9-16), and a final group of three stanzas which stress that all, high and low, must meet death (17-28). Moreover, Harrison emphasizes the pair of future participle in the last stanza (27 exitura, 28 impositura), similar to moriture (Dellius) of the first stanza, and highlights how the ring-composition is the key message explaining that the future of humans is predetermined. Death is also the cardinal theme of 
the other ode of philosophical argument, 2, 14 to Postumus. ${ }^{18}$ Here Horace's tone is more concerned than the 2, 3 and 1, 4 and 4, 7, other carmina in which death is the dominant theme. There is also a close connection between 2,14 and 2,3, also addressed to a rich property owner who cannot take his wealth with him after death: both poems stress the inevitability of death $(2,3,4-8$ and $2,14,13-14)$, expressed by the verbs enaviganda, visendus, linquenda.

Melancholy reflections on death were a commonplace of Greek poetry from the earliest times, in particular, Alcaeus (fr. 38A V.) has several points in contact with ode 2,14. Here as in Horace we have Sisyphus Aeolides and a river of the underworld. The remedies against the fear of death is obsessive among Epicureans (cf. Cic. nat. deor.1,86) and especially Lucretius. According to Harrison, the echo in lines 21-24 of Lucretius' famous satirical presentation of the insignificance of leaving behind one's family in death at 3, 894-901 is remarkable. Here the Horatian text reinstates the fear of loss of loved ones and worldly goods too easily dismissed by the radical Lucretius. In fact, this is not the only occasion in which Lucretius' lines have been reworked as a genuinely pathetic lament. Horace feels the need to accommodate Lucretian radicalism to a more conventional ideological framework, and once again presents a more moderate version of his excessive predecessor. Horace does not project himself into the position of the dead, as Lucretius does. For the person who is alive, lives well, and loves and enjoys life's gifts, the thought of death is painful. Epicurus' consolations may help a man who has largely become independent of pleasure by submitting himself to Epicurus's ascetic discipline, yet Horace, with his paupertas, is not an ascetic. He is hedonist and knows how to enjoy life without excess; he refuses to take refuge in reasonings that contradict the principles of every philosophy that makes bodily pleasure the ultimate touchstone of human happiness. By contrast, the closing stanza of Horace's final poem in Book $2(2,20)$ presents a more straightforward version of the Lucretian approach to death.

Moderation of passion is also a key idea in erotic matters. The poems 2, 4, 2, 5 and 2, 8 concern the theme of love. The ode 2, 4 is addressed to Xanthias, a typical slave male name for Aristophanes and in Athenian culture, and clearly represents an inversion of the traditional poetic teasing by poets of their friends about the unsuitable status of their beloved. The poem naturally exploits the elegiac motif of servitium amoris (the lover is enslaved to a slave). Harrison's commentary to 2, 4 is particularly focused on intertextuality, here related to the motives of epic and elegy.

The ode 2,5 is an example of lyric interaction with another literary genre, epigram. Here in six Alcaic stanzas the poet addresses the topic of a girl not

${ }^{18}$ See the commentary by Nisbet-Hubbard ad loc.; their tentative identification with the Postumus of Prop. 3.12 is attractive. 
yet ready for love. The first three stanzas seem a complete unity, in which the poet urges himself to wait until the girl is ripe (1-12). As scholars have noted, this is clearly related, also for the style and the repetition of nondum ("not yet"), to an epigram of Philodemus, addressed to Lysidike, too young for love now but soon to attract her lovers $(A P 5.124=16$ Sider $)$. However, the ode 2, 5 is a clear allusion to the fr. 417 PMG of the sixth-century Greek poet Anacreon of Teos, well known for his comparisons of girls with young animals (cf. frgg. 346 and 408), addresses a young girl as a "Thracian filly", avoiding the poet's sexual attentions. The poem's last stanza clearly refers to the epic story of the concealment of the young Achilles on Scyros amongst the girl attendants of Deidamia and the unmasking of his female disguise by the stratagems of Odysseus, sent to take him to Troy (hence sagacis . . . hospites). This episode, known from Statius' Achilleid, was almost certainly part of the epic repertoire in the archaic and Hellenistic period. The use of this myth to describe the attractions of an epicene boy adapts this heroic material for the pederastic world of erotic lyric, but once again this is an instance of generic interaction and enrichment. As the first half of the poem harnesses Greek epigram to a lyric context, so the final stanza includes an epic theme into the rich and flexible texture of the Odes. ${ }^{19}$ The 2, 8 addressed to Barine is a poem full of cross-references in the four books of the Odes. The men-eater Barine, probably a hetaira, with a speaking name recalling the one of a fish and suggesting sexual "delicacies" analogous to fish for eating, has much in common with Pyrra $(1,5)$ and the young boy Lygurinus $(4,1$ and 4,10$)$. The theme of the arrogant youth, not troubled by the effects of old age, is recurrent in the Greek lyric poetry and in Horace: but the young eromenos always find the tables turned, like in Alcaeus 8 G-P ("your leg is getting shaggy, Nicander...") and in Phanias 1 G-P and Meleager 90 G-P. Harrison draws attention to the intertextual links with Alcman 3, 61-74 $P M G$, proposed by Henry Spelman, ${ }^{20}$ but the poems picks up elements from Call. Ep. 25 Pf. Another poetic generic interaction in this ode is Roman loveelegy. Barine strongly looks like the attractive but untrustworthy puellae of Propertius, Tibullus and Ovid, and in the last two stanzas of Horace's poem we recognize the key topics of elegiac erotic discourse: the militia amoris in the image of pubes and the servitium amoris in servitium and domina. At line 19 the impia domina is the woman who violates the pietas of erotic fidelity (cf. Ov. Ars 2, 321 and ThlL s.v. pietas, vol. X, 1, $2233,13)$. The lovers are amusingly crowded together indoors rather than shut out individually on the threshold (the exclusi amatores). This suggests, according to Harrison, that they are privileged young men confident enough to occupy her house, like the suitors of the Odyssey who similarly fail in

${ }^{19}$ Horace alludes to the disguise of Achilles on Scyros in Ode 1, 8 .

${ }^{20}$ H. Spelman, "Alcman 3 PMGF and Horace C. 2.8", ZPE 192, 2014, 23-8. 
their erotic quest for Penelope. So «the mythological parallel matches that the sown men in 17 crescit, and the idea of Barine as an amoral Penelope is ironically entertaining», argues Harrison ad loc.

The last ode I will examine is part of those addressed to Maecenas, respectively $2,12,2,17$ and 2,10 . The first one, ode 2,12 , is particularly significant because it is one of the most famous examples of the recusatio, along with Vergil georg. 3, 41 and Propertius 3, 9. Harrison explains - in the brief introductive section before the ode's commentary - the history of this literary feature, that goes back to the preface of Callimachus' Aetia as at Satires 1, 10, 31-5. Thanks to the help of the Muse, Horace can state that writing an epos about the celebration of Augustus is not in the poet's lyric repertoire and he is convinced that Maecenas would celebrate the gesta Augusti better in prose history. Particularly interesting but difficult to solve is the question of the mention of the name Licymnia (used also by Virgil) in the fourth stanza. ${ }^{21}$ Horace's interest in the domina Lycimnia stresses the centrality of erotic relationships in his lyric world. Since a Ps.-Acro (on sat. 1, 2, 64), commentators have supported the idea that Lycimnia could represent a real person, in particular Maecenas' wife Terentia. Harrison faces the issue with the right amount of caution: this identification creates some difficulties. It is rather strange that Horace talks with a confidential tone about the wife of a friend and illustrious person, and it is especially strange that the poet alludes not his own lover, as we would expect, according to the tradition of recusatio, but that of his addressee. The final stanzas are focused on Lycimnia and on the two male friends' mutual appreciation of her appeal: she is seen as an attractive young girl perfect to join the young girls who worship the Goddess Diana. The matching of Lycinia's charms with the traditional wealth of the East (lines 21-4) reminds the readers that in the end this is a person for hire. Harrison writes that «here there is also an implicit suggestion that the riches to be gained by conquest (and to be celebrated in epic) are inferior to the (lyric) enjoyment of a beautiful woman, thus reinforcing the recusatio of the poem's first half: allusions to Persia/ Parthia $(21 \mathrm{n}$.) and to Arabia $(24 \mathrm{n}$.) point to the contemporary sphere of actual or potential military campaigns» (p. 148).

4. The text of Horace is not as problematic as that of many Latin poets. In this last part of my article-review I will discuss some of Harrison's editorial choices included in the critical text, such as variants and new conjectures. Harrison emphasizes, in the short chapter "Text" in the Introduction, that the sources of previous conjectures are fully documented in the Oslo database.

${ }^{21}$ Harrison does not do enough with Sutherland's suggestions that Lyde and Licimnia in 2.11 and 2.12 are metapoetic embodiments of Horatian lyric. Cf. E. Sutherland, "Literary Women in Horace's Odes 2.11 and 2.12", in Defining Genre and Gender in Latin Literature, edited by Batstone and Tissol, New York 2005, 193-210. 
I start with the first conjecture proposed by Harrison, that is pectus in 2 , 1,20 , in place of the transmitted vultus (or voltus), accepted by Shackleton Bailey and by Nisbet-Hubbard. Harrison prints his proposed conjecture, pectus, in the apparatus rather than the text and explains his choice in the commentary. Pectus, unlike vultus, gives, according to Harrison, the desired meaning in the line: in fact, pectus is doubtless the seat of the fear (cf. ThlL X 1, 914, 18-19), and the military reference seems to be generic and not towards a specific battle. ${ }^{22}$ Elisa Romano, in her commentary, ${ }^{23}$ argues that vultus would be an allusion to the fact that at Pharsalus Caesar ordered his men to hurt the Pompeians in the face. According to Nisbet-Hubbard, this could be a reference to the fact that Asinius Pollio, the addressee of the ode, took part in the battle.

Another conjecture proposed in Harrison's 2, 5, 13 apparatus, but not printed in the text, is the proper name Ferox (who is, in this case, the addressee of the ode) instead of the adjective ferox, also in order to alleviate the potential awkwardness with the accounting metaphors in the following lines. I am not sure, however, that ferox is problematic enough to need a conjecture. The adjective, as Nisbet and Hubbard as well as Harrison himself note, is used of spirited animals (see OLD s.v. ferox 3b), a metaphor that Horace applies elsewhere in the poem to Lalage. A central idea in this stanza is that situations will reverse, and the word ferox underscores one important reversal: Lalage will go from untamed, animalistic heifer to implicit victim of wild, animalistic time. When Lalage comes of age, she will no longer be desirable to the addressee.

At 2, 12, 9 Harrison proposes the conjecture $t u$ ipse in place of the transmitted tuque. According to Romano, it is difficult to explain this abrupt passage, which arises from the overlapping of two different thought patterns. On the one hand, Horace means that Maecenas is also led by nature to devote himself to genres different from the epic, while on the other hand, he contrasts his own lyric with the historical work that Maecenas will write. The -que could have an adversative value, but according to Nisbet-Hubbard ad loc.: "the sentence is pointing in the same direction as its predecessor». According to Harrison the -que should really express a parallel between $t u$ and another previously mentioned person, whereas Maecenas is the subject of both sentences in the poem. It could express an implicit contrast between Horace' potential work and that of Maecenas. In conclusion, Harrison points out that: "the problem would be solved by reading tu ipse, which marks the

${ }^{22}$ Harrison was not wrong to have sought a different solution in the text than the transmitted vultus. On pectus as the site of fear, particularly in the horses cf. Lucr. 5, 1315-17 terrificas capitum quatientis undique cristas, / nec poterant equites fremitu perterrita equorum / pectora mulcere et frenis convertere in hostis. Even in the problematic Lucretian context there seems absolutely no reference to a precise battle.

${ }^{23}$ E. Romano, Orazio, Odi ed Epodi, vol. II, Commento, Roma 1991, ad loc. 
appropriate contrast well. $\mathrm{Tu}$ would then begin a new sentence in mid-verse as it does at $1,14,15$, with a strong sense-break at the caesura of the asclepiad as at $1,15,26 ; 1,24,2 ; 3,16,18$, providing an appropriate contrast for me in 13 , setting Maecenas' potential prose against Horace's actual verse» (p. 151).

The bibliography, though necessarily selective, is cited generously. To conclude, this valuable edition and commentary is an essential resource for students and scholars working on Horace, and offers a lucid and effectively critical reading of the text and the history of the interpretation of Horace's Odes. 